\title{
TTR
}

Traduction, terminologie, re?daction

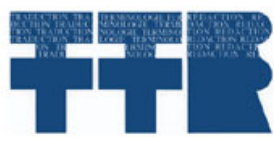

\section{Poetry as Knowing}

\section{Barbara Folkart}

Volume 12, numéro 1, 1er semestre 1999

Poésie, cognition, traduction I

Poetry, Cognition, Translation I

URI : https://id.erudit.org/iderudit/037352ar

DOI : https://doi.org/10.7202/037352ar

Aller au sommaire du numéro

\section{Éditeur(s)}

Association canadienne de traductologie

ISSN

0835-8443 (imprimé)

1708-2188 (numérique)

Découvrir la revue

Citer cet article

Folkart, B. (1999). Poetry as Knowing. TTR, 12(1), 31-55.

https://doi.org/10.7202/037352ar

\section{Résumé de l'article}

Poésie et connaissance - Comme les sciences pures, la poésie est avant tou une entreprise cognitive tendue tout entière vers la recherche de vérités voire de la Vérité. Son propos n'est nullement de " faire joli » : pas plus que la biologie moléculaire ou l'astro-physique, elle ne vise à être un art d'agrément. Elle cherche au contraire à entrer plus avant dans la matière brute du monde, nous incitant de ce fait à fouiller le flou de notre existence.

Pour ce faire, la poésie travaille en marge du langage reçu. Pratique contre-idiomatique, elle s'insurge contre le déjà-perçu, le déjà-lexicalisé, le déjà-dit. Et la mise en forme poétique - qu'elle soit « libre " ou bâtie à partir de contraintes prosodiques - joue un rôle primordial dans cette entreprise de décapage et de découverte. La forme du poème n'est décorative qu'à l'ignare. Pour qui sait lire, elle est fonctionnelle au plus haut degré.

En donnant forme à l'informe, en bouleversant nos habitudes langagières, perceptuelles et cognitives, la poésie nous arrache à nos vérités toutes faites. Elle nous force à arriver par la voie de l'affectivité à des connaissances neuves, ou à une saisie viscérale de ce que nous pensions savoir déjà. D'où sa fonction maïeutique.

C'est le refus du déjà-dit qui fonde la singularité du langage poétique et qui rend la poésie réfractaire à la traduction. La plupart des traducteurs, cependant, envisagent la traduction comme affaire de réplication. On ne saurait méconnaître plus radicalement la dynamique de la poésie.
Tous droits réservés (C) TTR: traduction, terminologie, rédaction - Les auteurs, Ce document est protégé par la loi sur le droit d'auteur. L’utilisation des 1999 services d'Érudit (y compris la reproduction) est assujettie à sa politique d'utilisation que vous pouvez consulter en ligne.

https://apropos.erudit.org/fr/usagers/politique-dutilisation/ 


\title{
Poetry as Knowing
}

\author{
Barbara Folkart
}

The answers to all the great questions lie in the grain of the world.

Hans Blumenberg

The everyday is always the hardest to explain.

Hubert Reeves

Like the pure sciences, poetry is first and foremost a cognitive undertaking, one of the most stringent modes of knowing that exist. Everything about it is shaped by the search for insight, or even truth. And the truth of a poem is, of course, something that goes far beyond paraphrasable propositional content : Yeats's elegy "In Memory of Eva Gore-Booth and Con Markiewicz" revolves about a proposition that has been around as long as humanity, but infinitely exceeds formulations like "all men are mortal" or even the beautiful, but already-said, "all flesh is like the grass". Truth in poetry would seem to be propositional content made available as direct experience, amplified into directly felt insight.

The irreducible truth of a poem is a direct outgrowth of its flesh - its imagery, soundplay, rhythms. It's the musicality of Yeats's elegy that makes us feel the mortality of the two lovely girls in silk kimonos : line 21, echoing the sound pattern of line 2 (Paulin, 1998, p. 3), juxtaposes the fact of their death with the recollection of their beauty, and makes us feel mortality, feel it directly, and so come to know it - precisely as we all of a sudden feel and know, in certain excruciating instants of real life. The poem, here, is doing the work of the epiphany-instants that come to all of us at mercifully rare intervals.

It's grotesque, I think, to set the esthetic up as an airy-fairy category on its own, and then make hard and fast distinctions between the esthetic and the cognitive. It's absurd to set the threshold of cognition so high that it excludes all but the rational, linear-logicked forms of mental activity : cognition, as the neuroscientists will tell you, is often downright illogical. And it's hugely erroneous to try and seal the cognitive and the emotional off from one another in leak-proof compartments. What gets called "the esthetic" is merely a special, high- 
intensity case of "the cognitive". Poetic cognition involves affect and body as well as the more disembodied kind of knowing that neuroscientists refer to as declarative intelligence.

A great poem, like a great theory in physics, is an inexhaustible inscape. ${ }^{1}$ The truth of such a poem takes reams and reams of exegesis to unpack, eluding and exceeding endless series of more or less propositional paraphrases. Translation, of course, is one way of unpacking a poem. Translations of poetry (as opposed to translations that succeed in being poems) are little more than successive approximations; it takes an unending series of translations, from the crib to the verse rendering, to even begin to approximate the poem, which remains an asymptote they'll never quite reach (the HumptyDumpty effect I've referred to elsewhere : see Folkart, "Inventing the Past", 1998).

Frankly, I don't know of any "strong" poetry, painting, sculpture, music that I don't feel relevant to the business of being in the world. Non-figurative art is not art that has nothing to say about the world : it does, after all, connect with the body and the emotions, which are prime ways of being in the world and knowing. For all their propositional opacity, Zukofsky's "80 Flowers" enact their referents (or at the very least, the poet's response to these referents, his way of experiencing them). A-referential poetry such as John Ashbery's creates, through its inflections, speech rhythms and discursive strategies, a compelling sense of subject-in-the-poem, and perhaps even a diffuse sense of world : a ceaselessly kaleidoscoping, soft-focus America, filmed through a lens smeared with Vaseline. Ashbery's poetry systematically deflects our desire for sustained reference to our common experience, but nonetheless constructs a sense of subject-inworld, and certainly, if Harold Bloom is to be believed, a statement about the business of making poetry out of world. Non-figurative art has its own system of truth value. It can still show us a great deal about the world, even as it tells us next to nothing : after all, the great answers all lie in the unexplored, as yet un-conceptualized grain of the world. And non-figurative art is just a special case : there is still poetry out there, masses of it, which fully intends to show, and sometimes even tell us, what it is to be in the world.

As opposed to light verse, which exhibits a huge degree of congruence with the already-said at the levels of both form and content, the business of poetry is to probe deeper into the as yet unconceptualized grain of experience, the hidden layers of our being in the world. By the end of a (successful) poem, the poet winds up knowing more than she thought she knew at the outset. The initial intuition (whether you want to think of it as a gift from the gods, or as

1 I'm reversing here the directionality of F. David Peat's comparison of poetry and physics (Peat, 1997, p. 114). 
sewerage backing up from the unconscious mind) unfolds into a statement that makes sense of at least some small part of the world.

And this is precisely what I mean by truth, as opposed to fact, which is the province of the instrumental uses of language, including the outermost, most immediate layers of science. Truth, for me, is an overarching reading of the world, a sense and unity and meaning constructed out of the raw materials of life - one of many possible models, but a model that distinguishes itself by its poignancy, its coherence, its elegance (elegance in the mathematical and scientific sense of simplicity, efficacy, being able to account for the most with the least). To the extent that they succeed, in places, in being poetry, Ted Hughes's recently published Birthday Letters are of interest for their truth content, not as fact-fodder for the obscene little cottage industry that's grown up around the Hughes-Plath marriage and its tragic outcome (hard to think of a greater insult to Plath's poetry, or of anything that would have outraged her as much as the way her poetry has been subordinated to her suicide).

Poetry, then, like the pure sciences, is a way of modelling the world. There is no incompatibility whatsoever between poetic vision and the insights generated by scientific or sometimes even scholarly discourse. And the feedback loops of artistic creation are pretty much the same as the feedback loops of scientific creativity : the intuitions that inform the best research can be remarkably close to the kind of insight poetry arises from. Art historian Beth Williamson has conjectured that the Virgins swooning at the foot of the Cross, in $14^{\text {th }}$ century European painting, were in fact experiencing, at their son's death, the physical sufferings they hadn't experienced in childbirth. Williamson, here, is operating out of a truly poetic insight : she is in fact recovering the creative impulse of the original artists. This intuition was probably building up as she slogged through her iconography, slide after slide; it then had to be confirmed (or disproved) with additional hard-nosed data. In other words, the spark is the way the data come together, all of a sudden, and this intuition goes on to inform the subsequent research.

You don't have to be religious to see how poetic Williamson's insight is, and how rich it is in theological implications. Even if her intuition turned out not to coincide with the intention of the original artists, it enriches our perception of these pieces, it's one of the readings that these strutture aperte can support. Insights like this have an esthetic fullness that's very much like the criterion of elegance in mathematics and physics.

Poetry, then, is about knowing. Poetry is not about being decorative : its language is anything but an ornamental overlay. Form is decorative only to the illiterate : the installation artist who sets out to co-opt the Holocaust, but winds up printing the Hebrew prayer she's 
using upside down; the tone-deaf academic who records his answerphone message over a hideously off-pitch re-taping of the Italian Concerto, in a bid to impress his callers with his musical sensitivity. For the competent receiver, art is acutely, intensely functional.

Nor is poetry about "expression", or "self-expression". The amorphously therapeutic, let-it-all-hang-out mode of writing ex-presses (squeezes out) nothing the writer didn't know before he started. While the authentic poem does indeed work by provoking an emotional response, its emotional impact, I will be arguing later on, is a response to its truth-value, not a wallowing self-indulgence. The emotional response to poetry is no more decorative than the form of the poem. Emotion is at the very core, not only of the poetic response, but even more importantly of the cognitive processes peculiar to art. In a word, the emotional inputs and responses involved in the processes of making and receiving poetry play a huge role and deserve more than the trivializing "expressive" slots allocated to them in the general-purpose "communicative" models that used to be so trendy in translation studies. ${ }^{2}$

Nor is poetry about being a pure language object: the poem - even the non-figurative one - is anything but a flat contraption, crafted and delighted in as a string of words at the surface of the paper, or a string of sounds in the air between a reader's mouth and a listener's ear. How could it be (given language's incoercible tendency to figure the extra-linguistic), when music (which could so much more readily be conceived of as a rule-governed, purely positional configuration) generates in us such an awesome and compelling sense of truth?

It's altogether fallacious to privilege the self-referentiality of a poem over its referentiality : the poetic text is a double structure, whose very constructedness (its lettre, its materiality, what it does with the raw materials inherited from the tribal idiom) is an integral part of the way the poem makes sense. It's the acoustic texture of Yeats's elegy, the way line 21 repeats the vowel sounds of line 2, that makes a statement about time passing, or rather shows time passing, and what it does to us. Poetry is a way of being in the world, and making meaning of it.

Authentic poems are "full", not flat entities : the outcome of the cognitive processes embodied in the poem is a rich and resonant

${ }^{2}$ Even Jakobson's model : sure, it's nice to be able to come up with a function centred about one of the actants in the communicative model, and the expressive function may even exist - but not in poetry. Self-expression is not what drives poetry. Poetry is about working towards an understanding of the world, and of the way we are in the world. 
sense of "real", not a bundle of sharp, disembodied particles of pure meaning like the noèmes the ÉSITiens like to bandy about. And contrary to the "in-one-end-out-the-other" view of meaning, the outcome of the cognitive process, at the reception end, is a joint construction between the poem and its receptor, not a re-construction of some abstraction pre-existing in the mind of the poet. In short, what I like to refer to as the "real" of the poem is, to use Hjelmslev's terminology, substance, not form : the rich, fuzzy-foisonnant, resonant sense of world that gets constructed more or less idiosyncratically by each reader, in function of her own vécu, around the core scenario provided by the poem.

Shakespeare, in his sonnets, may indeed have been working within the elaborate set of formal constraints analyzed in Helen Vendler's recent book (see Paulin, 1998). Sonnets are easy to write, and there's nothing implausible about a virtuoso poet's wanting to "up the ante", just to see what will happen : changez les contraintes, il en sortira autre chose (Burgelin, 1996). After all, formal gaming was so highly developed in the late middle ages and on into the Renaissance that it kept a number of literary scholars busy, back in the sixties, taking Villon apart in search of encrypted obscenities. But anagrams, couplet ties, and the like, are merely constraints, boundary conditions, part of the givens (exactly like Pérec setting himself the task of writing La Disparition without once using the letter -e, and seeing what kind of lexis and syntax he'd be forced into by the unavailability of forms like $l e$, or past participles of the first conjugation). And such actualized preconstraints are perhaps the least interesting aspect of the poems' textures and textualities. How Shakespeare's sonnets work, and have worked for centuries of receivers, is by creating, through their textures, a sense of "real" and a sense of subject, that urgent personal voice (Nandy, 1998, p. 5) which is what readers have been responding to over the centuries : mind-games are fine, but the language play of the sonnets serves vision, and emotion.

Art, I would claim is always full : it nudges the receiver into constructing a something and a someone behind the canvas or the page. Even when it enters the realm of the abstract or the a-referential, it is never just a mind-game : a totally non-figurative Jackson Pollock speaks to the viewer's body and emotions, through its rhythms and colours. Art is art by its ability to create world.

Pushed to the extreme, my position is that a string of words without a world behind it is not a text, let alone a poem. Nor can a string of words without a sense of subject behind it be a poem. That sense of subject is as much a textual construct, or rather a construct extrapolated out of the text, as is the "real" that gets constructed in the reader's mind - and it takes a full-formed text to create such a sense of subject. (True, even the klunkiest string of words will create a kind of sense of subject - except that the subject you extrapolate from a 
klunky string of words is a klutz, not someone you'd be interested in knowing.)

Pushed to the extreme, my position is that the sense of "an urgent personal voice" that arises in the transaction between reader and poem is a condition sine qua non of the poetic experience. What I am not talking about here is the trivializing category of "individuality" that gets slotted into the all-purpose communicative models - the ones that reduce poetic language to "occasional personal idiosyncracies" and "singularities", and treat "voice" as a whimsical oddity, a quirk or a fluke. Such models are incapable of coming to terms with what the poet is doing with her language; they fail to understand that poetry is a serious undertaking with a serious outcome.

In short, poets are no more in the business of making pretty, or letting it all hang out, or constructing gratuitious, airy-fairy, disconnected-from-the-real word-contraptions than are molecular biologists or computer nerds. What poets actually try to do, I believe, is put themselves into un-mediated contact with the grit of existence, the grain of the world (which, as Hans Blumenberg once remarked, is where the answers to all the great questions lie).

Digging into the continuum is a cognitive imperative : in order to maintain our sense of contact with the "real" we have to probe deeper and further into it, and we're probably hard-wired to do so. Not only is the world inexhaustible (semiosis is indeed bottomless), but the already-said has a way of drying up and peeling away from the real, failing us, faltering out from underneath us, desiccating into repetitive truism. Whether we're doing science or writing poetry, we have to be periodically "shorn of our preconceptions" if we are to "reconstruct our consciousness of reality in a more perfect order"3. I like to call it restless semiosis : in order to do justice to the world, poets delve deeper into its grain, deeper than ever before into the amorphous business of being.

This they do by "making it new". Poetry is a "counteridiomatic" practise, one that grates against the words of the tribe, its received ideas and its verities - the already-said, the already-thought, the already-perceived. The already-known is a repository of tribal

${ }^{3}$ I'm quoting here from German philosopher Hubert Crehan and American poet Kenneth Sawyer, both cited on page 2 of the documentation accompanying the National Gallery of Canada's permanent collection of Barnett Newman, Mark Rothko, Jackson Pollock et al. The full quote from Hubert Crehan is:

[...] the monstrous black and red shapes [...] evoke a spiritual charge akin to those profound emotions produced by the occasional scientific or philosophical utterances that reconstruct our consciousness of reality in a more perfect order. 
experience, abstracted from the messy continuum, and cleaned up. The lexicon is an abstract grid, a glossy veneer over the mess and murk of the real. The poet reverses the process of abstraction, reconstitutes some of the mess behind the lexicon, turns words back into world and tries to make sense of the raw new layers she's just uncovered. Poetry, to borrow Richard Wilbur's beautiful line, loses all that it touches back to wonder.

Poetry, like any other radical cognitive undertaking, challenges the templates on which categorical perception is founded, tries to deracinate our deep-rooted preferences for what we have previously been exposed to. Templates are inherently abstractions arrived at by filtering out any aspects of the real considered irrelevant to the business at hand. But the new is always on the fringes of the business at hand - the new is what got filtered out when the previous set of templates formed.

As opposed to the "cooked" knowledge of the tribe, the schemata and the categorical perceptions that override fresh input from the world, what the poet works with is the buzz of actual perception. There's nothing like being forced up against the real, with the slick veneer of the already-known peeled back, to make you know. Consider the TWA disaster, in the summer of 1996 - weeks and weeks of media coverage, words on words, photos, story lines fraying themselves threadbare. Then, 18 months later, the starkly laconic excerpts from the air traffic controler's tapes : flat professional pilot voices, one reporting an explosion at nine o'clock, flat professional traffic controller voices juggling flights and scanning for the missing aircraft, and then a single voice, pilot or air-traffic controller, saying in his flat American twang : that must have been him - God bless him. Finally, at the edge of that reiterated instant, you felt you knew what had happened.

At its best, poetry, too, operates at the edge of the instant. A teen-age Rimbaud gropes a half-naked servant girl, and the big trees swishing along the windows put us right into the resonant core of that afternoon. And here is Ted Hughes, more than forty years after the fact, writing of Sylvia Plath, the day he married her:
In that echo-gaunt, weekday chancel
I see you
Wrestling to contain your flames
In your pink wool knitted dress
And in your eye-pupils - great cut jewels
Jostling their tear-flames, truly like big jewels
Shaken in a dice-cup and held up to me.

These lines are remarkable for the way they pull Plath back out of the flux, bodily, in the astonishing physical, emotional, spiritual vibrancy 
she must have had, standing in the chancel of that church, at the age of 24. The cognitive impact of the poem - that stunning sense of exactly how Plath was on that June afternoon in 1956 - arises from the way the poem inhabits its instant, bringing it from latent to full-blown truth, forty years after the fact. The truth of Hughes's poem is in the way it does justice to the instant.

Language, too, has to be renewed, if poetry is to fulfill its cognitive vocation. Do not use the rotted names, wrote Wallace Stevens : the words of the tribe encapsulate the knowledge of the tribe. What Meschonnic (un travail dans les ressources du langage), Berman (parlance; un texte qui est premier dans son propre espace de langue) and Ladmiral (du français potentiel) were all talking about (if they could only have got their act together) was using language innovatively, actualizing its latent ressources in a way that makes it adequate to the insights it needs to convey, empowering it to do justice to the world. (As far as I'm concerned, the whole sourcier-cibliste flap is a giant cockup. Respecting the otherness of the text has nothing to do with replicating its linguistic micro-structures, and everything to do with coming to terms with it as an original, un texte qui est premier dans son propre espace de langue, a text that innovates within its own cultural and language framework, un texte qui fraie.)

And "form", in authentic poetry, whether or not it evolves out of set prosodic constraints, plays an all-important part in making language new enough so that it no longer clouds the world with its ready-made vision. As in mathematics, where elegance is what distinguishes the genius proof from the hack proof, as in the pure sciences, where the criterion of mathematical beauty can be a helpful guide, form provides a powerful cognitive impulsion, one that forces the poet into knowing more than she thought she did. The prosody, rhythm and soundplay of an authentic poem, like the stylized constraints of, say, quantum physics, play an essential role in the construction of new truth-models.

Here again, the contrast with light verse is instructive. Form, in light verse, is freestanding, and ostentatious. Its deliberately intrusive nature is part of what makes light verse fun. Systematic endstopping ensures that the presence of the line is felt, line after line; rumpy-pumpy scansion makes the metrical grid inescapable; rhymes are as outlandish as possible, with maximal phonetic overlap and grotesque rather than enlightening lexical overlaps (actually, close-tozero overlaps) - Yule : pasta-fasoul, or suitor : computer : do to 'er, in limericks. as opposed to hard : heart in a "serious" poem). Form, in light verse, is its own function; its sole purpose is to be form, blatantly, unmistakably so : light verse s'avance en se désignant du doigt. Content-wise, there is a high degree of adequation with the alreadysaid. Clichés may actually be cultivated; images must on no account be so fresh, or so true, as to take our breath away. Above all, there is wit 
in light verse, but not vision. Poetry and light verse, then, are radically different ways of being in the world, they have altogether different finalities and operate out of radically different stances.

The form of an authentic poem is never obtrusive, let alone freestanding : you cannot peel it way from what the poem has to tell us. The language of a poem is no more amovible than the equations in a biochemistry textbook. What ultimately gets analyzed as metaphor is a discovery procedure, a cognitive break-through (or at the very least, a cognitive tension that may resolve itself in deeper insight). Imagery puts us into the pulp of the instant; rhythm is the body's way of moving us into the transcendent (and in the grave my bones will sway, says the Hebrew prayer of glorification; just think of all the stompin and swayin that goes on at gospel services). Soundplay and imagery manufacture unforeseen cognitive relationships out of phonetic and visual similarities : profound images and rhymes (as opposed to trivial ones) induce meanings that are newer, and go deeper, insights that are fresher, and more authentic, and will stay with us longer, than the meanings of the lexicon.

Poetic form - a line like Robert Lowell's bright sky, bright sky, carbon scarred with ciphers - establishes a profound link between the esthetic and the cognitive, via the affective and the physical. Neurologically speaking, there's probably nothing the least bit mysterious about the sound-sense coupling posited by Jakobson (the famous statement to the effect that in poetic discourse, any similarity at the level of sound induces similarity or dissimilarity at the level of meaning) : sound similarity induces the receiver to hold the words together in his working memory, thus setting them up for comparison and pre-disposing him to discover an overlapping or an antioverlapping of the two bundles of semantic features. ${ }^{4}$ The more illuminating the overlap, the greater the discovery, or "uncovery" value of the rhyme. In other words, soundplay and rhyme are a mechanism for making us attend to the words involved, thus bringing to the surface any latent similarities or dissimilarities at the level of semantic features. (I am not referring here to the half-assed view that there exist preencoded sound-emotion pairings, with specific sounds invested, once and for all, with specific emotional values; phonostylistics, as far as I'm concerned, belongs in the same trash bin as the theories of abstract art Adam Gopnik has referred to, "earnestly dopey in their insistence that abstract art mechanically encrypted particular emotions, with big red blotches equalling excitement, droopy forms making you feel sad, and so on" (Gopnik, 1998, p. 75).

\footnotetext{
${ }^{4}$ Which is precisely what happens when Tom Paulin finally discovers why line 21 of the Yeats elegy has always brought him to the verge of tears: the longer span of the coupling (19 lines) explains why it took years for Paulin to conceptualize what his ear and his heart's ear had understood the very first time, perhaps, he ever heard the poem.
} 
Yet the recourse to after-the-fact categories such as "metaphor", "imagery", "sound play" is misleading and profoundly reductive; I have no intention, here, of buying into the static-sclerotic "literary devices" mindset, useful as it may be for more perfunctory forms of discussion. I find it profoundly repugnant to reify and inertialize something as proactive, as heuristic, as fluid as the writing of poetry into something called "poetic language", which can then be broken down, good-burgherly, into a hardware store of tricks 'n tools.

The pedantic focus on "figures" is a trivializing, a nonpractitioner's view of writing, one that postulates a freestanding entity knowable as "literary language" and then degrades it to an inventory of spare parts such as metaphor, alliteration, sound-play - tricks of the trade that get pulled off the shelf or out of the toolbox. What I despise about this view is the way it reduces writing to categories of the already-said, before it even gets written : analysis, with its ready-made categories, comes after the fact; writing, though, is inaugural. Writing is frayage.

In opposition to the profoundly inertial "literary devices" view of things, I see writing as a discovery procedure, un saut dans le vide, avec l'inévitable risque de se casser la gueule. The writer who produces what will later come to be analyzed as metaphor is taking the world in and giving it voice, at an instant of particular intensity and authenticity. Metaphor is process not product, structuring, not structure, perception, not percept. What will later - once it has cooled off and fallen into the domaine of the already-said - be analyzed as a rhetorical procedure is quite simply the way the poet was being in the world as she struggled against the words and world of the tribe. What drives segments that will later be perceived as sound-play are pulsions, not the decision or the desire to use alliteration. Juxtaposition is the unconscious processing its experience, the non-linear logic of images and affect, a logic of the lower levels, the unsemiotized regions of experience - those for which we have no ready-made schemata and labels. Writing poetry, in a word, is not a linear-logicked, get-me-tothe-top-of-the-heap career move.

In any authentic poem, then, what gets analyzed after the fact as "device" is anything but. The formal patternings of a poem are a way of making sense of the world. The sound and sense similarities that get referred to as metaphor, imagery and rhyme generate new insights, by forcing unexpected overlaps between previously unrelated fragments of experience and inducing common ground among disparates. What we react to as rhythm (not metre) is a way of being in the world; it's the body, breathing, moving, desiring, setting us up for what generally gets referred to as the spiritual. After all, mind is flesh, and so is what gets called "soul". 
Form I like to think of as the body of truth. And poetry - as opposed to the abstractified, bloodless wisdom which we all, as proper members of the tribe, have stored in us - poetry is carnal knowledge of the world. Knowing through sensory inputs of all sorts (as opposed to categorical perception) is a fundamental way of "knowing new". The feedback loop between body and emotions has received lots of attention : physical input plays a major role in stimulating emotional reactions - which in turn manifest themselves through various arousal systems and seem, indeed, to be an evolutionary mechanism for making us attend to physical inputs. I'll be speculating later on about the role emotions play in the cognitive pathways set in motion by poetry.

Every bit as important is the feedback loop between bodily experience and cognition, the way art and understanding are grounded in the body. One thing that's always struck me, in the realm of music, is how the utterly physical dance-rhythms so evident in, say, the Bach suites for unaccompanied cello or violin are a way into an utterly transcendent statement about the world :

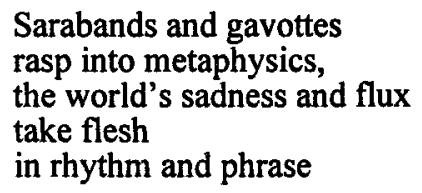

This sort of pathway, from the carnal to the cognitive, is by no means unique to the arts : physicists like David Bohm and Albert Einstein are reported to have placed great trust in bodily perception as a way of working out even the most abstruse theoretical constructs. Already, as an undergraduate grappling with the kinetics of the gyroscope, Bohm is said to have got into the skin of a gyroscope, so to speak:

Once, as he was walking in the country, he imagined himself as a gyroscope, and through some form of muscular interiorization, he was able to understand the nature of its motion. In this way he worked out, within his own body, the behavior of gyroscopes. The formulae and the mathematics would come later, as a formal way of explaining his insight.

From very early on in his scientific career, Bohm trusted this interior, intuitive display as a more reliable way of arriving at solutions. Later, when he met and talked with Einstein, he learned that he too experienced subtle, internal muscular sensations that appeared to lie much deeper than ordinary rational and discursive thought (Peat, 1997, p. 36).

And it's the sense of embodiment, I would claim, that gives rise to the impression of veridiction in the poetry that moves us. What 
Hughes gives us, in the last lines of his "Pink knit dress" poem, is the vibrancy, the intensity of the young Sylvia Plath - a sense of how she really was. In this stanza, at least, Hughes has pulled Plath back from the brink of myth and stereotype and cheap ideological exploitation he has given her to us in the flesh. And he's done it so much better, in seven lines, than all the diatribes spewed out by people who, in the last analysis, don't give a shit about her poetry.

Poetry, then, is a mode of knowing that owes much of its power to the way it mobilizes direct, bodily perception. And our response to poetry (at once a response and a signal that we are in the presence of truth) is a bodily one. Emily Dickinson (\#1480) writes of The fascinating chill that music leaves. We're all familiar with the hairraising sensation (it's actually called the pilomotor reflex) we get when we're unusually moved by an idea or a piece of art : human beings respond to the highest mental and spiritual achievements of their culture with the same reflex that raises the hairs on a dog's backs.

By giving it form, making it new, forcing us out of the lexicalized verities that have gone stale on us, poetry makes us feel our way to new truths, or to a gut knowledge of old ones. Poetry isn't the only type of artifact that can give us the impression of being dangerously close to some god flaming in a bush : a beautiful scientific or mathematical demonstration will also do it for you, as will a particularly elegant idea, whether in the free state or embodied in a machine. I like to call it the burning-bush syndrome, and for me it's a signal that an unusually high level of truth, or ordering, has been reached, or at least that the idea, or the poem has enabled you to acceed to a higher level of understanding. For me, this "high-energy" state that accompanies whole-body perception is a litmus test, a sure sign that a scientific theory or a poem has pulled together strands that had formerly seemed unrelated, that the painting or the idea or the machine in which the idea is embodied has moved you forward, in a cognitive sense. ${ }^{6}$

The compelling quality of art, the way it makes you attend to $i t$, overriding all but the most urgent business at hand, is a sign (that you recognize), it has something to say that's of importance to you exactly as the emotional systems wired into our brains as specialized

\footnotetext{
' I'm quoting novelist Pat Barker (1995 [1993], p. 232), who is in turn basing her remark on the work of the early twentieth-century neurologist and social anthropologist W.H.R. Rivers.

${ }^{6}$ This, incidentally, might account for why the poetry that blows $\mathrm{X}$ away may well leave $\mathrm{Y}$ cold : maybe $\mathrm{Y}$ already knew what $\mathrm{X}$ has only just comprehended through the poem - assuming, of course, that poetry doesn't leave $Y$ totally indifferent, which is okay, too.
} 
neural circuits have evolved to make us attend to physical inputs from situations that are crucial to our survival and reproduction.

Poetry, in short, makes you feel your way to truth. Hence its maïeutic function. Authentic poems provide only the thin-rich indications you need to work it through for yourself : poetry, said Walt Whitman, seldomer tells a thing than suggests or necessitates it. They work by juxtaposition and evocation rather than linear-logicked discourse, because that's what the unconscious works with, and the unconscious (in the neuroscientific even more so than the Freudian sense) is where much of our affect comes from.

Which brings me to the cognitive uses of emotion - more precisely, to the role of affect in the cognitive pathways peculiar to art. As both a reader and a writer of poetry, 1 would postulate that affect is, in its own way, a mode of knowing. The wiring of the brain is such that "the connections from the emotional systems to the cognitive systems are stronger than the connections from the cognitive to the emotional systems" (LeDoux, 1996, p. 19). And for good reason : the emotional systems, as parts of the ancestral brain, have a more immediate involvement with survival and reproduction. My knowledge of neuroscience wouldn't fill a thimble, and godforbid that I should lapse into the kind of crap science academics in the humanities have so rightly been taken to task for, but I'm inclined to guess that the emotions aroused by poetry are integrated into specific neural circuits, with physical inputs such as rhythm and soundplay and visuals producing somatic arousal which in turn creates emotional responses that get "echoed" in the regions of the cortex which are the site of declarative intelligence - cognition in the narrowest sense of the word. (It would be truly interesting to see if people whose emotional reactions have been blunted by damage to their spinal cords, which severely limits the amount of somatic input they receive, also lose part of whatever receptivity to art they may once have had.)

What makes the esthetic so rich is the way the cognitive feeds back into the neural circuits in the ancestral brain. The musical experience, for example, is a culturally conditioned emotional feedback loop if ever there was one. There's nothing inherently "sad" about the minor mode; the "sadness" we associate with the minor keys is a cultural convention that has taken hold in Western music only in the last couple of centuries. And once we get beyond the raw material of the musical idiom, far subtler phenomena come into play : the piercing sadness we perceive in so much of Ravel's writing for the piano must be the end product of a supremely intricate feedback from the cortex to the ancestral brain and back. Our response to art may well build on evolutionary priming, which predisposes us to attend to certain stimuli more readily than to others. 
It's clear to me, anyway, but I'm predicating this on my own type of response to poetry, that truth which has lost its emotional edge dries out into verity. The "winnowing process by which art begins to look more like its period than like itself" (Gopnick, 1998, p. 77) coincides with a loss of emotional intensity. Texts that no longer speak to us with an "urgent personal voice" get lexicalized and resorbed into the idiom. Newness is an affective, as well as a cognitive imperative. The miracle texts have enough individuality, enough originality, depth, validity and authenticity to remain parole du matin, to borrow Berman's lovely expression (Berman, 1985, p. 96).

The link between affect and cognition works both ways. Novelist Pat Barker has remarked that the consolation of her uncompromisingly desolate World War I trilogy, The Ghost Road, lies in the trilogy's form. What I think she meant was that form could make sense and pull something, at least, back out of the flux. She may well be wrong : the slaughter of young men in the trenches, like the Holocaust, has nothing to teach us - but we're compelled to worry meaning out of atrocities as a way of consoling ourselves. translation?

So how does all this tie in with the problematics of

The very fact that poetry is so intolerant of the already-said is what makes it refractory to translation: the poem taps into the unused potential of its linguistic raw material to forge its own idiosyncratic signifiers (hence the irreplicability of what Berman referred to as $l a$ lettre). Most practitioners, though, conceive of translation as a way of replicating (their own limited version of) what's already there. The result is seldom, if ever, poetry.

As everyone knows (or claims to know), there are translations of poems, and then there are translations that actually are poems. The latter are what I refer to as writerly translations. On one side, then, there are the weak, non-writerly, rote translations produced by wee, timourous, reverential beasties cowering in awe of The Original : uninhabited strings of words, lip service as void as those uninhabited performances one sometimes gets in theatre or classical dance (we've all seen the dancer merely going through the motions, or the actor mouthing lines instead of acting from inside his character). On the other side, there are the writerly, inhabited translations produced by strong translators - people who have the talent, the skills, and the attitude to take charge. In the hands of such people, even error becomes a creative mechanism.

And it seems to me that carnality - the materiality of the text, the sense of "real" and the sense of "subject" it creates - is one of the things that make the difference between writerly and rote translation. Consider Ted Hughes's wonderfully embodied rendering of the 
Salmacis and Hermaphroditus story - one of those sexual harassment incidents Ovid does so well in the Metamorphoses. Hughes turns his teenage Salmacis into a boisterous sexual predator, gifts her with a ferocity and a horniness far beyond anything you'd find in your LatinEnglish dictionary under flagellum, premere or inhaerere. He sexualizes the story right down to its tiniest details : Utque sub aequoribus deprensum polypus hostem/continet ex omni dimissis parte flagellis (IV, 366-67) comes over to us as :
And as the octopus -
a tangle of constrictors, nippled with suckers, that drag towards a maw -
embraces its prey

Illa premit commissaque corpore toto/sicut inhaerebat, "pugnes licet, inprobe", dixit,/"non tamen effugies" (IV, 369 - 70) becomes :

As she crushes her breasts and face against him

And clings to him as with every inch of her surface.

'It's no good struggling,' she hisses.

Berman, I suppose, might have complained that Hughes, here, a dépassé les textures de l'original et enfreint ainsi l'éthique de la traduction $^{7}$. I disagree : these details are all latent in the original formulation, for the textures of a poem extend far below its surface, and offer writerly possibilities for the translator who has the talent to recognize and reactualize them. Hughes has worked with the substance, not the form, of the poem's contents; with his sense of body, his sense of visuals, he has instinctively chosen latent features to bring to the surface, instinctively decided how he wanted to actualize the potentialities of the rather more abstract dixit and premit commissaque corpore toto sicut inhaerebat ${ }^{8}$.

Plath, in her diary (which makes this story writing, not anecdote), tells of her first encounter with Hughes at a Cambridge party, Hughes and Plath both drunk, both on the make, he ripping her earrings and headband off, she biting his face till the blood ran, a perfect match for each other in terms of sheer inventive horniness. The story (independently of its value as verifiable fact) is immensely moving now she's dead and he is too; its animal energy has somehow migrated into Hughes's rewrite of the Salmacis episode. Hughes's version gives the twentieth century English reader something of the jouissance Ovid's contemporaries must have had - the physical,

\footnotetext{
7 "Le contrat fondamental qui lie une traduction à l'original interdit tout dépassement de la texture de l'original" (Berman, 1985, p. 58).

${ }^{8}$ Literally: "She presses [against him], clinging [to him] with her entire body, as if attached".
} 
sensual, esthetic, emotional and cerebral pleasures, all at once. This, in a word, is appropriation at its most glorious.

Writerly translation, in short, is about mastery, both of the real and of the means of textual production. Which brings me to what I perceive as the talent gap between poets and translators. Untrendy as it may be to say so, my feeling is that translators of poetry are distinctly less talented, on the average, than the poets they translate. (Just as translators of scientific texts are usually, and almost by definition, less gifted as scientists than the authors whose texts they render.) Pouvoirdire (to use Annie Brisset's term) isn't just about external constraints (the iron-fisted institution littéraire); it's also about individual deficits. While it may or may not be true that Maurice Edgar Coindreau "couldn't have got away with" translating the vernaculars of Faulkner's novels, it's abundantly clear that a) Coindreau might have been hard pressed to find suitable vernaculars in the Hexagonal sociolectal configuration (the old problem of anisomorphism), b) even if equivalently marked vernaculars were available, it's unlikely that a city-slicker like Coindreau would have had the sort of direct, day-today familiarity Faulkner and Steinbeck had with the vernaculars they used as raw material, and finally c) if Coindreau had anything like the talent of a Faulkner, he would have been writing novels of his own, not translating.

And even aside from questions of talent, as with all other areas of translation, there's a gap at the level of ownership (and not just in the relatively trivial sense of intellectual property rights and payment). The author writes out of what she knows, the translator is forced to tag along. Few and far between are the translators of Faulkner and Steinbeck who have the same gut knowledge of places and vernaculars Faulkner and Steinbeck did; Marie-Odile Fortier-Masek finds herself all of a sudden having to build bridges and dismantle bombs in the wake of a Michael Ondaatje. No author would risk compromising the integrity of her novel by writing out of a world she had no real grasp of, but the translator bloody well has to.

Finally, there's an attitude gap (yes, attitude in the street sense). As opposed to the poet translating, the translator (or the academic translating) is less willing to take ownership of the real of the text and the text of the text. Consider a short sample of the way Eugenio Montale's "Notizie dall'Amiata" has been translated by both the American academic Irma Brandeis and the American poet Robert Lowell : 
Montale

Notizie dall'Amiata

Il fuoco d'artifizio del maltempo

sarà murmure d'arnie a tarda sera.

La stanza ha travature tarlate ed un sentore

di meloni

penetra dall'assito.

Le fumate

morbide che

risalgono una valle

d'elfi e di funghi fino

al cono diafano

della cima

m'intorbidano i vetri, e ti scrivo di qui, da

questo tavolo

remoto, dalla cellula

di miele

di una sfera lanciata

nello spazio...
Brandeis

News from Amiata

The fireworks of

threatening weather

might be murmur of hives

at duskfall.

The room has pockmarked

beams

and an odor of melons

seeps from the store-room.

Soft mists

that climb from a valley

of elves and mushrooms to

the diaphanous cone

of the crest cloud over my

windows

and I write you from here,

from this table,

remote, from the honey cell

of a sphere launched into

space... 
Lowell

I.

Come night,

the ugly weather's fire-cracker

simmer

will deepen to the gruff buzz of beehives.

Termites tunnel the public room's rafters to sawdust,

an odor of bruised melons oozes

from the floor.

A sick smoke lifts from the elf-

huts and funghi of the valley -

like an eagle climbs our mountain's bald cone,

and soils the windows.

I drag my table to the window, and write to you -

here on this mountain, in this beehive cell

on the globe rocketed through space.

Brandeis's rendering is what I would call a "no-name translation". Il fuoco d'artifizio del maltempo/sarà murmure d'arnie a tarda sera becomes The fireworks of threatening weather/might be murmur of hives at duskfall; Le fumate/morbide che risalgono una valle/d'elfi e di funghi fino al cono diafanoldella cima m'intorbidano $i$ vetri gets rendered as Soft mists/that climb from a valley/of elves and mushrooms to the diaphanous conelof the crest cloud over my windows. Brandeis seems trapped in the words of the source poem, incapable of entering, or knowing (in the carnal sense) the world the poem opens onto. Rote translation can only deal with the already lexicalized : the room has pockmarked [ < tarlate] beams, writes Irma Brandeis, and soft mists [...] cloud over my windows and I write you from here, from this table. Brandeis gets so hung up on micro-structural details she deals incorrectly with longer spans of syntax : sarà murmure d'arnie a tarda sera gets mistranslated as might be murmur of hives at duskfall - an odd mistake, and a telling one, in a translation that is clearly so preoccupied with fidelity.

Where Brandeis works word-bound, stumbling over the surface of the text, Robert Lowell takes the image, makes the sounds and visuals his, and runs with them. A sick smoke lifts from the elf-huts and funghi of the valley [...] and soils the windows, writes Lowell, and Termites tunnel the public room's rafters to sawdust, and Come night, the ugly weather's fire-cracker simmer will deepen to the gruff buzz of 
beehives : note the visual and verbal and rhythmical expansion, the adequation of sound to referent. Lowell, here, is writing more or less directly out of the "real" triggered by the source text in his head and gut, not through the scrim of somebody else's words-pace Meschonnic 9 . At the level of both sound and image the latent potentialities of Montale's poem are actualized, in Lowell's poem, and made flesh - yet another illustration of the fact that the textures of a poem extend well below its surface, offering latent possibilities for the writerly translator to actualize.

The derivative, non-writerly translator is happy to stay within the safe reaches of the bilingual dictionary. The words on the page in front of him are static and hugely inertial artifacts - a Patrimony (hence the anxious, never-ending questionings about just how far one is "allowed" to go with The Author's Original). Which is why rote translation is of next to no use in poetry, where words are things-to-dothings-with (to such an extent that I'm tempted to go full circle and see poetic language, paradoxically, as the most instrumental of all the uses of language). The difference between a rote translator like Brandeis and a poet like Lowell is much like the difference between the run-ofthe-mill physics undergraduate who, when asked to come up with an explanation of gyroscopic motion, will "learn the various formulae involving conservation of angular momentum, and produce an explanation in a relatively mechanical and formulaic fashion", and the young David Bohm, who, needing " $a$ direct perception of the inner nature of this motion" resorted to imagining himself a gyroscope (Peat, 1997, p. 36).

Both Brandeis and Lowell make the occasional outright error. But it's interesting to compare the types of errors they make. Where Brandeis has misread the verb form sarà, Lowell is wrong about morbide (which actually does mean something like Brandeis's soft), and renders it as sick. Lowell's sick throws its coloration over the entire piece, generating the dysphoric drag my table to the window, dirty green serge, soils, etc. Assuredly, this is a misreading. But $A$ sick smoke lifts from the elf-huts and funghi of the valley [...] and soils the windows is writing, writing that creates a sense of place, and atmosphere. Lowell's misreading, I'm convinced, is more than just an inadequate knowledge of the source language; it's very close to what Harold Bloom has called misprision, the strong poet's defence mechanism against invasion by a strong predecessor. Brandeis's Soft

${ }^{9}$ Dire que l'écrivain va du réel au livre et le traducteur d'un livre à un livre, c'était méconnaître [...] qu'il y a toujours déjà eu des livres entre l'expérience et le livre (Meschonnic, 1973, p. 360). Bien entendu! Our readings, like every other aspect of our experience, get absorbed into the consciousness we bring to the world. But the rote translator, fixated on the words in front of him, is incapable of marshalling this agregate experience to help him "see through" to a "real" behind the set of words he has in front of him. 
mists that climb from a valley of elves and mushrooms [...] cloud over my windows fails to go beyond mere lexical equivalence. Lowell's trajectory could be summed up as poem to world, and world to poem.

Where poets like Lowell create a sense of world behind their words, rote translators produce texts that are defective, texts that fail to create, "behind them", a sense of "real" and a sense of "subject" which is just another way of saying that rote translations, useful as they may be as cribs or introductions, fail to be poems.

For me there's not the slightest doubt that Lowell's text is superior to Brandeis's, whether you use the critic's yardstick or the poet's intuition to do your comparing ${ }^{10}$ : Brandeis's is a no-name string of words, a preliminary translation, maybe, but not a full-fledged poem. Yet, when I presented this corpus at a departmental seminar, Lowell's rendering went over like a lead balloon : there were mutterings of qu'est-ce qui permet de dire que le texte de Brandeis n'est pas un poème, and more mutterings of c'est du Lowell, c'est pas du Montale (peut-être bien : mais mieux vaut du Lowell que de la Brandeis). And ages ago an academic by the name of José-Luis Ramos voiced similar objections to what he called Lowell's "egotistical" rendering of a sonnet by Quevedo : Lowell, among other things, he complained, "changes all the visual imagery from stone context to the wood context of New England" (Ramos, 1980, p. 384). What Ramos of course failed to see was that Lowell, in reactualising Quevedo's sonnet, "lui avait donné le grain de son vécu à lui [Lowell], ... les rugosités de l'expérientiel avec lequel lui se trouvait dans le même rapport d'authenticité que Quevedo avec son Espagne du XVIT siècle" (Folkart, 1991, pp. 422-423). Even theorists have a hard time getting away from the idea that translation must be more of the same, firmly ensconsed in the already-said.

The oddest thing is that Lowell's derived poem is vastly superior to Brandeis's string of words, not only on its own terms, but equally by reference to the Montale from which it derives. Brandeis's rendering, even at the purely semiotic level, is flawed by internal inconsistencies that rob it of coherence. Seen as an "equivalent" to

10 The critical model, being, of course, an after-the-fact approximation to the poet's intuition. I'm no longer inclined to the use of grids and hyper-grids (there are faster ways to get the same results), so I'll limit myself to pointing out, in Lowell's poem, the instinctive way pattemings of voiced and unvoiced items are played off against one another, buzz vs sick smoke, so that the $\mid z /$ sound-field that peaks in the voiced buzz plays off against the unvoiced /s/ items accumulating a few lines on (where Lowell's play on $/ f /$ and $/ s /$ matches Montale's /f/v/ play). While Brandeis's lines inevitably contain voiced and unvoiced items, such items are distributed sporadically, with no sign of an intuitively organised patterning comparable to the way $/ \mathrm{s} /$ 'deepens' to $/ \mathrm{z}$ /, in the early lines of Lowell's poem, then softens back to $/ \mathrm{s} /$. 
Montale, it's plain inaccurate. Just the difference between fireworks and fire-cracker simmer encapsulates the superiority of Lowell's poem. Fire-cracker simmer gives a far better representation of the real to which Montale's poem points, both in terms of motivation (the soundto-referent adequation of fire-cracker simmer) and denotationally (Montale's fuoco d'artifizio is far-off thunder heard on an afternoon of mists wisping around the mountain - sound, that is, not visuals. Firecracker simmer is perfect for that intermittent crackle petering out at the end of the day (murmure), whereas the visual pyrotechnics of Brandeis's fireworks are utterly incompatible with the "soft mist" that comes creeping up from the valley, just a few lines later).

But Robert Lowell, I guess, just rubs academics the wrong way when he translates. Tant pis pour les universitaires! Ultimately, I would claim, the people who keep getting scandalized by the poems Robert Lowell derives from other people's work are showing their indefectable attachment to a certain conception of what translation has to be. It's not just the practitioners who cleave to the already-said. A good many theorists, whatever the ideological colouring of their writings, have a tendency to behave as if translation must not only replicate the source text, but must be seen to replicate it. This is theoretical lockjaw, intensely hostile to any suggestion that translation might be considered as a playful, potentially innovative activity. Inevitably, this iron-fisted, Loi-du-Père mindset obscures what actually turn out to be finer, or higher, or deeper levels of equivalence.

As will be obvious from the way I've set this essay up, I take issue quite strongly with the notion that the "instrumental", or "utilitarian" discourse of science and technology has somehow contaminated, let alone taken over, the way we see translation. ${ }^{1}$ Yes, it's perfectly true that the denotational approach, the emphasis on (immediate) propositional content, is deeply rooted in both the practice and the theory of translation. But this dominance of the denotational has nothing to do with the supposed "imperialism" of scientific and technical discourse. It's an offshoot of the dominance, in both the practice and the theory of translation, of the replicative mindset, which puts "fidelity", or the more respectable "accuracy", ahead of the intrinsic quality of the target text. And "replicative" works out to be "denotational", more often than not, since accuracy is easier to discern at the level of small structures and short spans of meaning.

"This notion is by way of becoming something of a topos in translation studies : see Venuti, The Translator's Invisibility, 1995, pp. 5-6, and the call for papers for this colloquium, which speaks of "un monde dominé par la technologie où l'on tend à privilégier la fonction 'utilitaire' de la traduction et à sous-estimer les textes qui ne s'identifient pas immédiatement avec la technoscience ou les discours de savoir". 
This is an impoverishment of the potential field of meaning suggested by the designation trans-latio. A more productive understanding of the term would lead to at least four nested categories : metatexts, the set of all possible transformations of the source-text; next, the subset of allolingual metatexts; then, inventive translation, or the subset of allolingual transformations which conserve the deepstructure hierarchy of functionally relevant features; and finally replicative translation, which requires that surface structures as well be carried over, right down to the denotational level (which is fine for instrumental discourse, for verse translation and for cribs, but of next to no use in rendering poetry as poetry).

The oddest thing of all, perhaps, is that while translation studies continues to grunt away behind an essentially "replicative" view of translation (quitte à fourrer tout le reste dans la catégorie proprement indéfinissable de l'adaptation), the most informed "donneurs d'ouvrage", so to speak, are calling for something quite different. Here's classicist Donald Carne-Ross talking about Christopher Logue's notoriously freewheeling, and notoriously splendid "Patrocleia" :

Logue, unencumbered by Greek scholarship [...], has managed to get inside [Homer's] poem again and has discovered that, after all these years, it is still breathing. [....] thanks to his irresponsible behaviour, Homer is on the move once more. The genie is out of the bottle. (Carne-Ross, 1963, p. 63)

Classical historian James Davidson goes even further. Reviewing a competent but uncompelling translation of Apollonius of Rhodes's Argonautika, he has this to say : "[...] perhaps it is time for liberties to be taken. It would be interesting to see the Argonautika violated" yes, he does say violated, and he spins his metaphor a bit further - "it would be interesting to see the Argonautika violated by a less brawny version of Christopher Logue" (Davidson, 1998, p. 9).

The Hellenists and presumably the Latinists, in short, are all for having poets go at the classical texts hammer and tongs (metaphorically speaking, of course). But we translation studies people know better than the poets - don't we? 


\section{References}

BARKER, Pat (1995 [1993]). The Eye in the Door. London-New York, Penguin-Plume.

BERMAN, Antoine (1985). "La traduction et la lettre ou l'auberge du lointain". Les Tours de Babel. Mauvezin, Trans-Europ-Repress, pp. 31150.

BURGELIN, Claude (8 mars 1996). "Georges Pérec : l'autobiographe et l'écrivain", conférence prononcée à la Maison française d'Oxford.

DAVIDSON, James (March 5" 1998). "Himbo". London Review of Books, pp. 7-9.

FOLKART, Barbara (1991). Le Conflit des énonciations : traduction et discours rapporté. Candiac, Les Éditions Balzac.

- (1998). "Inventing the Past. The Re-enactment of Medieval Poetry". TTR XI, 1, pp. 11-32.

- (1986) "Opacification and semiosis : Ulysses as double structure". Semiotic Theory, Proceedings of the Third Congress of the International Association for Semiotic Studies. Berlin, Mouton de Gruyter, pp. 259-268.

GOPNIK, Adam (March $16^{\text {th }}$ 1998). "The Power Critic". New Yorker, pp. 70-78.

HUGHES, Ted (1994). "Salmacis and Hermaphroditus", in After Ovid. Hofmann, M. and J. Lasdun, eds. London, Faber and Faber, pp. 114117.

- (1998). Birthday Letters. New York, Farrar Strauss Giroux.

LE DOUX, Joseph (1996). The Emotional Brain. New York, Simon and Schuster.

MESCHONNIC, Henri (1973). "D'une linguistique de la traduction à la poétique de la traduction". Pour la poétique II. Paris, Gallimard.

NANDY, Dipak (February 19 19 th 1998 ). "Letter to the editor". London Review of Books, p. 5.

PAULIN, Tom (January 22 $2^{\text {nd }} 1998$ ). "In the Workshop". London Review of Books, pp. 3-8.

PEAT, F. David (1997). Infinite Potential. New York, AddisonWesley. 
POUND, Ezra [1953] (1984). Translations. London, Faber and Faber.

RAMOS, José L. (1980). "Translation as a semiotic process". Comparative Literature Studies, vol. 17, no. 4.

VENUTI, Lawrence (1995). The Translator's Invisibility. London-New York, Routledge.

ABSTRACT : Poetry as Knowing - Like the pure sciences, poetry is first and foremost a cognitive instrument, one of the most rigorous modes of knowing that exist. Everything about it is shaped by the search for insight, or even truth. Poets are no more in the business of "making pretty" than molecular biologists or computer nerds; they put us into un-mediated contact with the grid of the world, force us to dig deeper than ever before into the amorphous business of being.

This they do by "making it new". Poetry is a "counter idiomatic" practise, one that grates against the words of the tribe, its received ideas and its verities. And "form" - whether "free" or forged out of constraints - plays an all-important part in making it new for us. Form is decorative only to the illiterate. For the competent receiver, it is acutely, intensely functional.

By giving it form, making it new, forcing us out of the lexicalized varieties that have gone stale on us, poetry makes us feel our way to new truths, or to a gut knowledge of old ones. Hence the maieutic function of poetry.

The very fact that poetry is so intolerant of the already-said is what explains the irreplicability or what Berman referred to as la lettre and makes the poem refractory to translation. Yet, most practitioners conceive of translation as a way of replicating what's already there. It's hard to imagine a more anti-poetic stance.

RÉSUMÉ : Poésie et connaissance - Comme les sciences pures, la poésie est avant tout une entreprise cognitive tendue tout entière vers la recherche de vérités voire de la Vérité. Son propos n'est nullement de " faire joli » : pas plus que la biologie moléculaire ou l'astro-physique, elle ne vise à être un art d'agrément. Elle cherche au contraire à entrer plus avant dans la matière brute du monde, nous incitant de ce fait à fouiller le flou de notre existence.

Pour ce faire, la poésie travaille en marge du langage reçu. Pratique contre-idiomatique, elle s'insurge contre le déjà-perçu, le déjàlexicalisé, le déjà-dit. Et la mise en forme poétique - qu'elle soit " libre " ou bâtie à partir de contraintes prosodiques - joue un rôle primordial dans cette entreprise de décapage et de découverte. La forme du poème n'est décorative qu'à l'ignare. Pour qui sait lire, elle est fonctionnelle au plus haut degré.

En donnant forme à l'informe, en bouleversant nos habitudes langagières, perceptuelles et cognitives, la poésie nous arrache à nos 
vérités toutes faites. Elle nous force à arriver par la voie de l'affectivité à des connaissances neuves, ou à une saisie viscérale de ce que nous pensions savoir déjà. D'où sa fonction maïeutique.

C'est le refus du déjà-dit qui fonde la singularité du langage poétique et qui rend la poésie réfractaire à la traduction. La plupart des traducteurs, cependant, envisagent la traduction comme affaire de réplication. On ne saurait méconnaître plus radicalement la dynamique de la poésie.

Barbara Folkart : School of Translation and Interpretation, University of Ottawa, C.P. 450, Succursale A, Ottawa (Ontario) K1N 6N5.

Courriel : bfolkart@uottawa.ca 